\title{
Morganella morganii Peritonitis Associated with Continuous Ambulatory Peritoneal Dialysis (CAPD) after Colonoscopy
}

\author{
Yukihiro Kimura ${ }^{1}$, Ayano Ito ${ }^{1}$, Kanyu Miyamoto ${ }^{1}$, Norihiro Suga ${ }^{1}$, Naoto Miura ${ }^{1}$, \\ Tomomichi Kasagi ${ }^{1}$, Yuka Yamagishi ${ }^{2}$, Hiroshige Mikamo ${ }^{2}$ and Hirokazu Imai ${ }^{1}$
}

\begin{abstract}
A 79-year-old man on continuous ambulatory peritoneal dialysis (CAPD) developed abdominal pain and cloudy peritoneal fluid two days after colonoscopy that revealed multiple diverticula. The white blood cell count was 9,000 cells $/ \mu \mathrm{L}$, C-reactive protein level was $6.86 \mathrm{mg} / \mathrm{dL}$, and the white blood cell count of the peritoneal fluid was 7,800 cells $/ \mu \mathrm{L}$, suggesting acute peritonitis. Empiric therapy consisting of cefazolin and ceftazidime slowly improved the patient's symptoms. The initial microbiological examination of the peritoneal fluid demonstrated Morganella morganii. He was changed from CAPD to hemodialysis. It is important to consider M. morganii peritonitis in patients with colonic diverticula.
\end{abstract}

Key words: acute peritonitis, continuous ambulatory peritoneal dialysis, Morganella morganii, colonoscopy, colonic diverticulum

(Intern Med 55: 165-168, 2016)

(DOI: 10.2169/internalmedicine.55.5971)

\section{Introduction}

Morganella morganii is a Gram-negative rod commonly found as normal flora in the intestinal tracts of humans, mammals, and reptiles or as environmental bacteria. Initially, M. morganii had been classified in the Proteus genus, and had been called Proteus morganii. In 1978, it was reclassified into the Morganella genus (1). A cluster of M. morganii infections occurred at a general tertiary hospital in 2006 (2), consisting of $61 \%$ wound infections and $39 \%$ urinary tract infections. M. morganii has been reported as the cause of urinary tract infections (3), arthritis (4), pericarditis (5), pyomyositis (6), sepsis (7), chorioamnionitis (8), ecthyma gangrenosum-like eruptions (9), meningitis (10), renal abscesses (11), and gas gangrene (12) in neonates or elderly immunocompromised patients or those with other serious underlying diseases.

M. morganii infections generally respond well to appropriate antimicrobial chemotherapy. However, its natural resistance to many $\beta$-lactam antimicrobial agents may lead to delays in proper treatment (13). We herein report a case of peritonitis due to $M$. morganii related to CAPD after colonoscopy with a review of the pertinent literature.

\section{Case Report}

A 79-year-old Japanese man was admitted to the Division of Nephrology and Rheumatology at Aichi Medical University Hospital for a fever, abdominal pain, and cloudy peritoneal fluid. Thirty years prior to admission, he was diagnosed with hypertension. One year before admission, CAPD was initiated for end-stage kidney disease. His regular peritoneal dialysis routine consisted of four exchanges of $1.5 \mathrm{~L}$ bags of $1.5 \%$ glucose solution. His daily urine output ranged from 400 to $1,200 \mathrm{~mL}$. Two days before admission, he underwent colonoscopy for an evaluation of diarrhea. Multiple diverticula were observed in the colon, and a diagnosis of diverticulosis was made (Figure). No pathologic organisms were detected. On the day of colonoscopy, he stopped peritoneal dialysis to empty and rest the peritoneal cavity. Several hours after the resumption of peritoneal dialysis, he developed abdominal pain with cloudy peritoneal fluid.

On admission, he was afebrile at $36.5^{\circ} \mathrm{C}$ and complained

${ }^{1}$ Division of Nephrology and Rheumatology, Department of Internal Medicine, Aichi Medical University School of Medicine, Japan and ${ }^{2}$ Department of Clinical Infectious Diseases, Aichi Medical University School of Medicine, Japan

Received for publication June 12, 2015; Accepted for publication August 2, 2015

Correspondence to Dr. Hirokazu Imai, imaihiro@aichi-med-u.ac.jp 


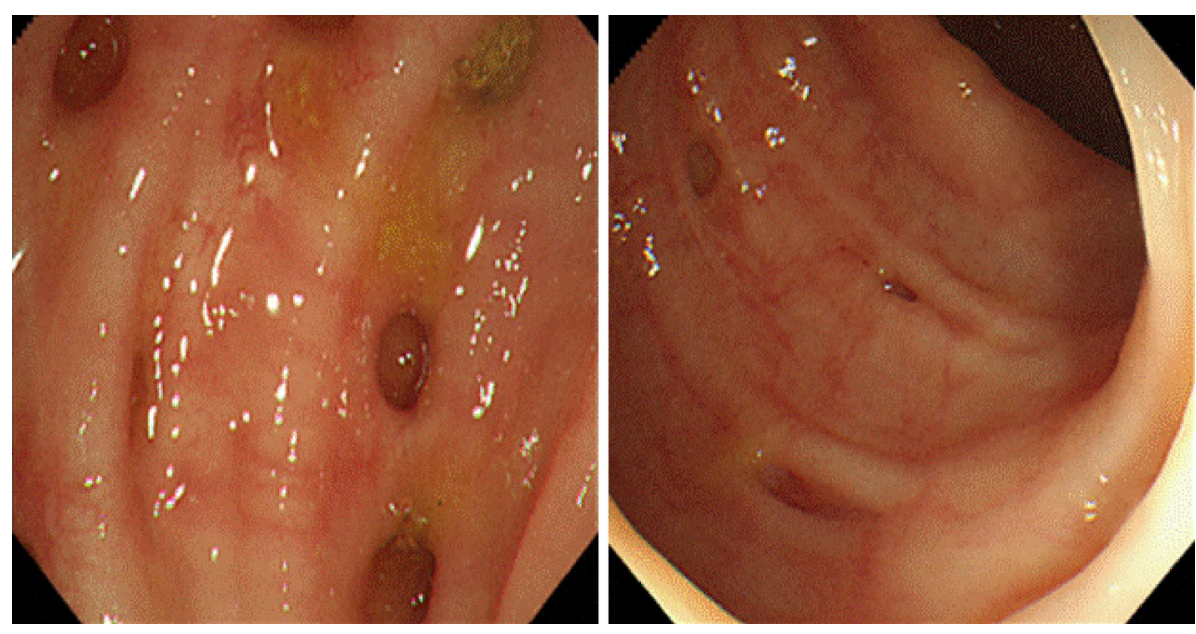

Figure. Colonoscopic examination. Multiple diverticula were observed.

of abdominal pain. His pulse was 53 beats/min and regular, and blood pressure was $178 / 62 \mathrm{mmHg}$. His body weight was $58.0 \mathrm{~kg}$ with $1.5 \mathrm{~L}$ of peritoneal fluid. A physical examination revealed a normal mental status, a clean surgical scar in the neck, and diffuse abdominal tenderness with rebound tenderness. There was no erythema or other signs of infection at the catheter exit site. Laboratory studies included a white blood cell (WBC) count of 9,000 cells $/ \mu \mathrm{L}$, hemoglobin $9.4 \mathrm{~g} / \mathrm{dL}$, hematocrit $27.9 \%$, platelet count $16.5 \times 10^{4}$ cells $/ \mu \mathrm{L}$, albumin $2.5 \mathrm{~g} / \mathrm{dL}$, blood urea nitrogen $61.9 \mathrm{mg} / \mathrm{dL}$, and creatinine $6.60 \mathrm{mg} / \mathrm{dL}$. The Na concentration was $137 \mathrm{mEq} / \mathrm{L}, \mathrm{K} 2.4 \mathrm{mEq} / \mathrm{L}, \mathrm{Cl} 101 \mathrm{mEq} / \mathrm{L}$, AST 29 U/L, and ALT $24 \mathrm{U} / \mathrm{L}$. The lactate dehydrogenase concentration was $302 \mathrm{IU} / \mathrm{L}, \mathrm{CK} 337 \mathrm{IU} / \mathrm{L}$, and CRP $6.86 \mathrm{mg} / \mathrm{dL}$. The WBC count of the peritoneal fluid was 7,800 cells $/ \mu \mathrm{L}$ (71.5\% neutrophils, $8.5 \%$ lymphocytes, and 20\% macrophages). A blood culture examination revealed no bacteremia.

On hospital day 5, after cefazolin (1.0 g/day) and ceftazidime (1.0 g/day) were started empirically, the WBC count of the peritoneal fluid became 51 cells $/ \mu \mathrm{L}$, and the CRP level was $2.0 \mathrm{mg} / \mathrm{dL}$. The initial peritoneal fluid bacterial culture grew out Morganella morganii resistant to cefotiam (CTM), sultamicillin (SBTPC), and fosfomycin (FOM), and sensitive to third-generation cephalosporins such as cefcapene pivoxil (CFPN-PI), ceftazidime (CAZ), and cefpodoxime proxetil (CPDX-PR). We continued CAZ for 16 days and discontinued cefazolin. The patient's clinical condition and laboratory data improved gradually. He was changed from CAPD to hemodialysis due to the risk of bacterial biofilm formation and recurrence of peritonitis due to multiple diverticulosis.

\section{Discussion}

Morganella morganii is a Gram-negative rod that is part of the normal flora of the intestinal tract in humans and other animals. Characteristics of this organism include indole production, ornithine decarboxylase, urease, phenyl- alanine deaminase, and growth in $\mathrm{KCN}$ (1). In addition, Morganella species are capable of producing $\beta$ lactamases (13). Initially, M. morganii was mainly identified as a cause of urinary tract infections (3), and it has subsequently been isolated in patients with pneumonia, wound infections, skin and soft tissue infections (2), nonclostridial gas gangrene (12), meningitis (10), and sepsis (7). Falagas et al. reported 24 patients infected with $M$. morganii over a four-year period in a general tertiary hospital in Greece with 650 beds (2). They noted that skin and soft tissue infections were the most common type of infections due to M. morganii. Only one patient had peritonitis secondary to appendicitis, and $58 \%$ of the patients in that series had polymicrobacterial infections. They also commented that $70 \%$ and $96 \%$ of isolated M. morganii were resistant to ceftriaxone, and amoxicillin/clavulanic acid, respectively. Chen et al. performed whole genome sequencing and identification of $M$. morganii (14). Out of 82,861 samples they examined, $M$. morganii was isolated in 1,219 samples (1.47\%) during a six-year period (2006-2011) in Taiwan. They found novel characteristics of $M$. morganii through an analysis of pathogenicity-related genes. In the present patient, M. morganii was resistant to cefazolin but sensitive to ceftazidime.

Regarding peritonitis due to M. morganii, Isobe et al. first reported a patient with spontaneous bacterial emphysema and peritonitis in 1994 (15). The second case was part of a case series by Falagas et al. (2). The first case of CAPDrelated peritonitis caused by $M$. morganii appeared in Turkey in 2010 (16). The second case occurred in Taiwan (17) and the third case was in Austria (18). The present case is the fourth such case so far reported in the literature (Table).

We changed the patient from CAPD to hemodialysis due to the risk of bacterial biofilm formation by $M$. morganii and multiple diverticulosis. M. morganii produces urease, which generates ammonia from urea, and is associated with crystalline bacterial biofilm formation on urinary catheters (19). It is able to survive in acidic conditions, and the urease it produces is activated in low $\mathrm{pH}$ environments. In addition, the present patient had multiple diverticula, which 
Table. Cases of Peritonitis Associated with Morganella morganii.

\begin{tabular}{|c|c|c|c|c|c|c|c|}
\hline Ref & Age & Sex & Condition & Complication & Treatment & $\begin{array}{c}\text { Duration } \\
\text { of antibiotic } \\
\text { therapy } \\
\end{array}$ & Outcome \\
\hline 15 & 55 & M & $\begin{array}{l}\text { spontanous } \\
\text { empyema }\end{array}$ & liver cirrhosis & $\begin{array}{l}\text { gentamycin, } \\
\text { third-generation } \\
\text { cephalosporin }\end{array}$ & 14 days & cure \\
\hline 2 & 33 & M & $\begin{array}{c}\text { appendecitis, } \\
\text { peptic ulcer } \\
\text { disease } \\
\end{array}$ & nephrolitiasis & $\begin{array}{l}\text { ceftriaxone, } \\
\text { metronidazole, } \\
\text { amoxicillin }\end{array}$ & 12 days & cure \\
\hline 16 & 55 & $\mathrm{~F}$ & CAPD & $\begin{array}{c}\text { Providencia } \\
\text { rettgeri }\end{array}$ & $\begin{array}{l}\text { changed to } \\
\text { HD } \\
\text { cefoperazone, } \\
\text { vancomycin } \\
\text { changed to } \\
\text { imipenem, } \\
\text { amikacin }\end{array}$ & 14 days & $\begin{array}{l}\text { cure } \\
\text { re-start } \\
\text { CAPD }\end{array}$ \\
\hline 17 & 62 & $\mathrm{~F}$ & CAPD & $\begin{array}{l}\text { two months } \\
\text { after } \\
\text { Prevotella } \\
\text { species } \\
\text { peritonitis }\end{array}$ & $\begin{array}{c}\text { cefmetazone was } \\
\text { changed to } \\
\text { ceftazidime }\end{array}$ & 10 days & cure \\
\hline 18 & 53 & M & $\begin{array}{c}\text { CAPD } \\
\text { diverticulosis }\end{array}$ & $\begin{array}{c}\operatorname{IgA} \\
\text { nephropathy }\end{array}$ & $\begin{array}{l}\text { conversion to } \\
\text { HD } \\
\text { ceftazidime, } \\
\text { vancomycin }\end{array}$ & $\begin{array}{l}13 \text { days } \\
\text { after } 4 \\
\text { months }\end{array}$ & $\begin{array}{l}\text { cure } \\
\text { re-start } \\
\text { CAPD }\end{array}$ \\
\hline $\begin{array}{l}\text { This } \\
\text { case }\end{array}$ & 68 & M & $\begin{array}{c}\text { CAPD } \\
\text { diverticulosis } \\
\text { post-colonoscopy }\end{array}$ & nephrosclerosis & $\begin{array}{l}\text { cefazolin, } \\
\text { ceftazidime }\end{array}$ & 16 days & $\begin{array}{l}\text { cure } \\
\text { conversion } \\
\text { to HD }\end{array}$ \\
\hline
\end{tabular}

is a weak portion of bacterial penetration, and can induce recurrent peritonitis. Imai et al. have reported barium enema examination-induced diverticulitis and perforated peritonitis (20). In Europe and the United States, 30-40\% of individuals over 60 years of age have diverticulosis, and the incidence increases with age. In Japan, the incidence of diverticulosis is approximately $20 \%$ in individuals over 60 years of age, compared to $5 \%$ in individuals younger than 40 years of age. This is the first reported case of peritonitis caused by M. morganii after colonoscopy. If patients have multiple diverticula, colonoscopy may induce bacterial peritonitis, sometimes $M$. morganii-related peritonitis. In the present case, we did not use antibiotics before colonoscopy. When we have to perform colonoscopy in patients on CAPD, cefditoren pivoxil, cefixime, levofloxacin, or norfloxacin is recommended as prophylactic antibiotics. Extreme care should therefore be taken during colonoscopy, especially in patients on CAPD.

The authors state that they have no Conflict of Interest (COI).

\section{References}

1. O'Hara CM, Brenner FW, Miller JM. Classification, identification, and clinical significance of Proteus, Providencia, and Morganella. Clin Microbiol Rev 13: 534-546, 2000.

2. Falagas ME, Kavvadia PK, Mantadakis E, et al. Morganella morganii infections in a general tertiary hospital. Infection 34: 315321, 2006.
3. Jones BD, Mobley HL. Genetic and biochemical diversity of ureases of Proteus, Providencia, and Morganella species isolated from urinary tract infection. Infect Immun 55: 2198-2203, 1987.

4. Schonwetter RS1, Orson FM. Chronic Morganella morganii arthritis in an elderly patient. J Clin Microbiol 26: 1414-1415, 1988.

5. Sica S, Di Mario A, Salutari P, et al. Morganella morganii pericarditis after resolvent splenectomy for immune pancytopenia following allogeneic bone marrow transplantation for acute lymphoblastic leukemia. Clin Infect Dis 21: 1052-1053, 1995.

6. Arranz-Caso JA, Cuadrado-Gomez LM, Romanik-Cabrera J, García-Tena J. Pyomyositis caused by Morganella morganii in a patient with AIDS. Clin Infect Dis 22: 372-373, 1996.

7. Salen PN, Eppes S. Morganella morganii: a newly reported, rare cause of neonatal sepsis. Acad Emerg Med 4: 711-714, 1997.

8. Johnson JR, Feingold M. Case of chorioamnionitis in an immunocompetent woman caused by Morganella morganii. J Matern Fetal Med 7: 13-14, 1998.

9. Del Pozo J, García-Silva J, Almagro M, Martínez W, Nicolas R, Fonseca E. Ecthyma gangrenosum-like eruption associated with Morganella morganii infection. Br J Dermatol 139: 520-521, 1998.

10. Samonis G, Anatoliotaki M, Apostolakou H, Souglakos J, Georgoulias V. Fatal septicemia and meningitis due to Morganella morganii in a patient with Hodgkin's disease. Scand J Infect Dis 33: 553-555, 2001.

11. Osanai S, Nakata H, Ishida $\mathrm{K}$, et al. Renal abscess with Morganella morganii complicating leukemoid reaction. Intern Med 47: 51-55, 2008.

12. Ghosh S, Bal AM, Malik I, Collier A. Fatal Morganella morganii bacteraemia in a diabetic patient with gas gangrene. J Med Microbiol 58 (Pt 7): 965-967, 2009.

13. Pitout JD, Sanders CC, Sanders WE Jr. Antimicrobial resistance with focus on $\beta$-lactam resistance in gram-negative bacilli. Am J Med 103: 51-59, 1997. 
14. Chen YT, Peng HL, Shia WC, et al. Whole-genome sequencing and identification of Morganella morganii KT pathogenicityrelated genes. BMC Genomics 13 (Suppl 7): S4, 2012.

15. Isobe H, Motomura K, Kotou K, Sakai H, Satoh M, Nawata H. Spontaneoius bacterial emphyema and peritonitis caused by Morganella morganii. J Clin Gasteroenterol 18: 87-88, 1994.

16. Atalay H, Güney I, Solak Y, Almaz E. First case of CAPD-related peritonitis caused by Morganella morganii. Perit Dial Int 30: 119121, 2010.

17. Tsai MT, Yeh JT, Yang WC, Wu TH. CAPD-related peritonitis caused by Morganella morganii. Perit Dial Int 33: 104-105, 2013.

18. Windpessl M, Prammer W, Asböck R, Wallner M. More on peritonitis by Morganella morganii. Perit Dial Int 33: 467-468, 2013.

19. Stickler D, Morris N, Moreno MC, Sabbuba N. Studies on the formation of crystalline bacterial biofilms on urethral catheters. Eur J Cin Microbiol Infect Dis 17: 649-652, 1998.

20. Imai H, Satoh K. Perforated diverticulitis after barium enema examination in a patient on CAPD. Nephrol Dial Transplant 12: 2758-2760, 1997.

(C) 2016 The Japanese Society of Internal Medicine http://www.naika.or.jp/imonline/index.html 